\title{
Skjeletta frå Stavanger domkyrkje - ei lang og innfløkt soge
}

\begin{abstract}
In 1967-68 an area under Stavanger Cathedral was excavated, which revealed more than 30 inhumations without any grave goods. Remains of 22 skeletons were boxed individually and sent to the Anatomic Institute at the University of Oslo for analysis. For some unknown reason they kept some of them and returned two boxes containing many bones in a commingled and fragmentary state to Stavanger. Since 2004, The Museum of Archaeology has aimed to revitalize these skeletons for research. Results of ${ }^{14} \mathrm{C}$-dates state that they all died before the erection of the church which took place in the beginning of the $12^{\text {th }}$ century. Osteometric sorting managed to combine some bones into individuals while analyses of stable isotopes gave insight into their diet. So far efforts to revitalize a miserable bone collection have added new understanding of past life conditions in SW Norway.
\end{abstract}

\section{Innleiing}

Det mest forteljande sporet etter menneske frå fortida er skjelett. Ved dei arkeologiske musea og ved De Schreinerske Samlinger, Universitetet i Oslo, finst i magasina eit rikhaldig humanosteologisk materiale. Ein av målsettingane til dei arkeologiske universitetsmusea er å aktivere samlingane for forsking. Dette kan i mange tilfelle vere krevjande då samlingane generelt er bygd opp og handsama gjennom lang tid med ulikt syn på og krav til innhald og dokumentasjon. Eit døme på dette (sjå figur 1) finst i magasinet ved Arkeologisk museum, Universitetet i Stavanger; bildet syner den største av to trekasser, heretter omtala som beinkassa, som skriv seg frå ei utgraving i Stavanger domkyrkje i 1967-68 og som er fylt med skjelettdelar utan sortering av innhaldet og med inga eller dårleg merking. Vi ynskjer i denne artikkelen å vise korleis nye metodar utvikla dei siste tiåra, saman med stort tolmod, har medverka til at ein likevel har kunne nytte dette materialet til å bringe fram ny kunnskap om menneska som levde i Stavanger i vikingtid og mellomalder.

\section{Undersøkingar i Stavanger domkyrkje}

Ein må gå attende i tid til 1960-talet då foreininga Domkirkens venner i Stavanger ønskte å restaurere austre del av krypten i Domkyrkja og innreie ein del av denne til utstillingsrom for gravsteinar. Leiinga ved Arkeologisk avdeling ved Stavanger Museum (no Arkeologisk 


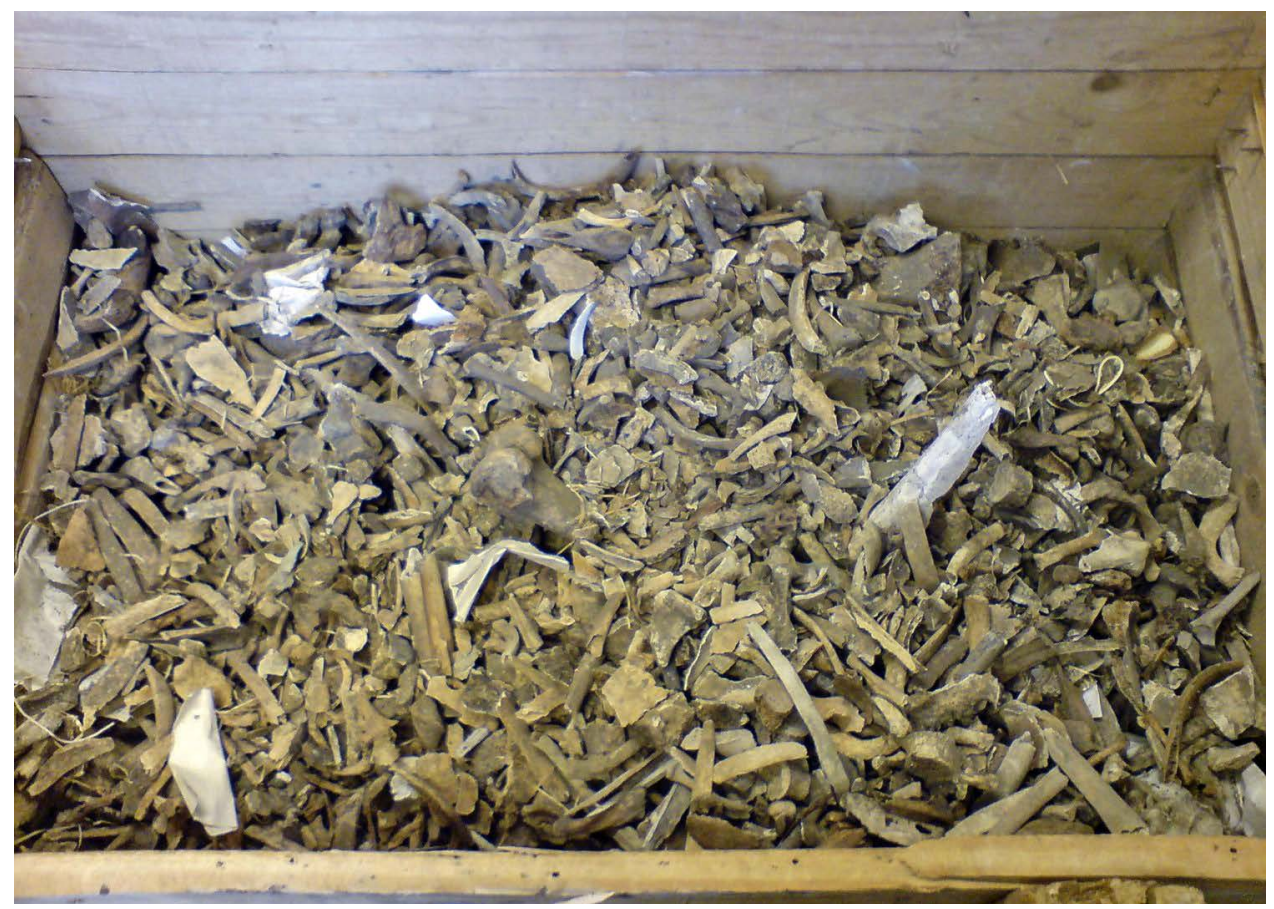

Figur 1. Den største kassa med menneskeskjelett som Arkeologisk avdeling ved Stavanger Museum fekk i retur frå Anatomisk institutt, De Schreinerske Samlinger. Foto: Sean Dexter Denham, AM, UiS (2010).

museum (AM)) tok kontakt med Riksantikvaren med førespurnad om ei arkeologisk undersøking før tiltaka vart satt i verk, og Riksantikvaren bad museet om å foreta naudsynte undersøkingar. Ein kjende til nokre tidlegare inngrep som var utførte inne i kyrkja. I åra 1860-1880 var det gjort restaureringsarbeid i Domkyrkja (Rolfsen 1968), mellom anna montering av ein stor, mura fyrkjel med luftekanalar under koret. Arbeida i grunnen var omfattande. I 1934 utførte stadsarkitekt Erling W. Nielsen etter rettleiing frå stipendiat Fredrik Macody Lund undersøkingar i koret, men det finst ingen publisert rapport frå dette arbeidet. Arkitekt Gerhard Fischer held fram med undersøkingar same år, vidare i 1940 og 1941, og med supplerande arbeid i starten av 1960-talet. Han var mest oppteken av å undersøke bygningsutviklinga og publiserte seinare resultata sine (Fischer 1964).

\section{Utgravinga 1967-1968}

Dei eldre undersøkingane tok i første rekkje sikte på å svare på ymse bygningshistoriske spørsmål. Det same var utgangspunktet for museet sine ønskjer for ei ny undersøking, men i tillegg ønskte ein å finne ut om det fanst graver som var skorne ned i grunnen i krypten, og om det var geistlege graver ved det noverande alterfundamentet. Elles var ein òg open for at alle typar av funn som kunne koma til syne, ville skape grunnlag for å reise nye spørsmål og problemstillingar. 
Undersøkinga i Stavanger domkyrkje starta våren 1967 med ei før-undersøking som mellom anna påviste ei grav med skjelett (Espedal 1968). Resultata frå denne danna grunnlag for ei utgraving som kom i gang i juli-august 1967 under leiing av Perry Rolfsen og vart endeleg avslutta i januar 1968. Opplysningane om resultata av utgravinga, presentert i det følgjande, er basert på utgravingsrapporten (Rolfsen 1968) samt anna arkivmaterial ved AM. Det går fram av desse kjeldene at undersøkinga omfattar eit området inne i kyrkja under golvet mellom langveggane på kvar side av koret og tverrveggen mot sør-søraust. Det samla arealet, som var omlag $140 \mathrm{~m}^{2}$, var oppdelt av murar som danna tre «rom», her nemnt som rom I-III (sjå figur 2, 3). Før-undersøkinga var utført i rom II som ligg på sørsida av muren parallelt med lengdeaksen i kyrkja.

Ein gjekk systematisk til verket. Utgravingsfeltet vart delt inn i eit rutenett på 1 x $1 \mathrm{~m}, \mathrm{og}$ ein grov mekaniske lag med tjukkleik på $10 \mathrm{~cm}$. Alle lausmassane vart sålda på sikt med maskevidde $5 \mathrm{~mm}$. Då utgravingane starta, var det ingen spor å sjå etter nedskjeringar. Ein fjerna først eit lag som var inntil $3 \mathrm{~cm}$ tjukt, og som inneheldt avfall frå moderne tid. Så kom ein ned på eit mørkt, delvis feitt lag som var mellom eit par cm og opp til 1,2 m tjukt, og i dette laget fanst store mengder dyre- og fiskebein, gjenstandar, skjørbrende stein og bitar av kol samt spikar og naglar som låg rundt om. Under delar av dette laget, på begge sider av midtmuren, låg eit kompakt lag dominert av trekol og med oske og skjørbrende stein kitta saman. Laget som hadde tjukkleik frå eit par $\mathrm{cm}$ til $35 \mathrm{~cm}$, skilde seg klårt frå laga over og under. Under kollaget påviste ein fire stolpehol som var mellom $20 \mathrm{og} 30 \mathrm{~cm}$ i diameter og mellom 13 og $34 \mathrm{~cm}$ djupe, fordelt med tre i rom II og eit i rom III og som saman danna så å seie ein trekant (figur 4). Jordmassen under trekollaget og mellom stolpehola var nærast kulturjord. I følgje Rolfsen (1968) kan det ha vore fleire stolpehol i dette området og mogelegvis finst enno intakte spor av slike under murane. Han påpeiker vidare at alle låg innafor utstrekninga til kollaget og difor truleg høyrer til ein konstruksjon knytt til dette.

\section{Menneskeskjeletta: in situ}

I rom I ved fyrkjelen, låg to samlingar av skjelett omtala av Rolfsen (1968) som skjelett nr. $30 \operatorname{og} 31$ (figur 2 og 3). Nr. 30 som var forstyrra av teglpilarane frå 1860-talet, inneheldt bein som låg hulter til bulter og var av minst fire individ kor eit var delvis intakt. Nr. 31 var òg kraftig forstyrra av tidlegare inngrep i samband med arbeid på staden. I rom II vart det tildelt 14 skjelettnummer (nr. 1 til 14) og i rom III ni (nr. 21 til 29) (sjå tabell 1). Nokre av skjelettnummera i desse romma inneheld òg delar av fleire skjelett, elles vart det funne mykje lause bein rundt om. Skjeletta var alle orientert aust-vest og låg på ryggen med hovudet $\mathrm{i}$ vest og i ca. $20^{\circ}$ vinkel i høve til lengdeaksen i kyrkja. Armane låg langs sidene, over bekkenet eller folda over magen. Det var mange jarnnaglar kring skjeletta, noko som tyder på at alle var gravlagde i kister som var sett ned i jordsmonnet. Ingen oldsaker vart funne ved skjeletta, og jorda rundt dei og i nedskjeringane var feit og svart. Alt i alt tyda funna på at gravene var kristne. Ved tidlegare gravingar under koret og i krypten hadde ein funne bein av menneske, men det kom likevel som ei overrasking at det no dukka opp så mange skjelett der det som tidlegare nemnt ikkje var teikn på søkk eller nedskjeringar i overflata slik ho sto fram i 1967.

Det vart skilt ut minimum 32 skjelett som låg i ulike nivå og som til dels var øydelagde av yngre gravleggingar (figur 5). Enkelte skjelett som delvis låg under ytterveggane eller midtmuren vart ikkje samla inn. Skjeletta og murane samt tilhøva i lausmassane og mellom lausmassar, murar, stolpehol, trekollag og skjelett er dokumenterte i ei rad med teikningar 


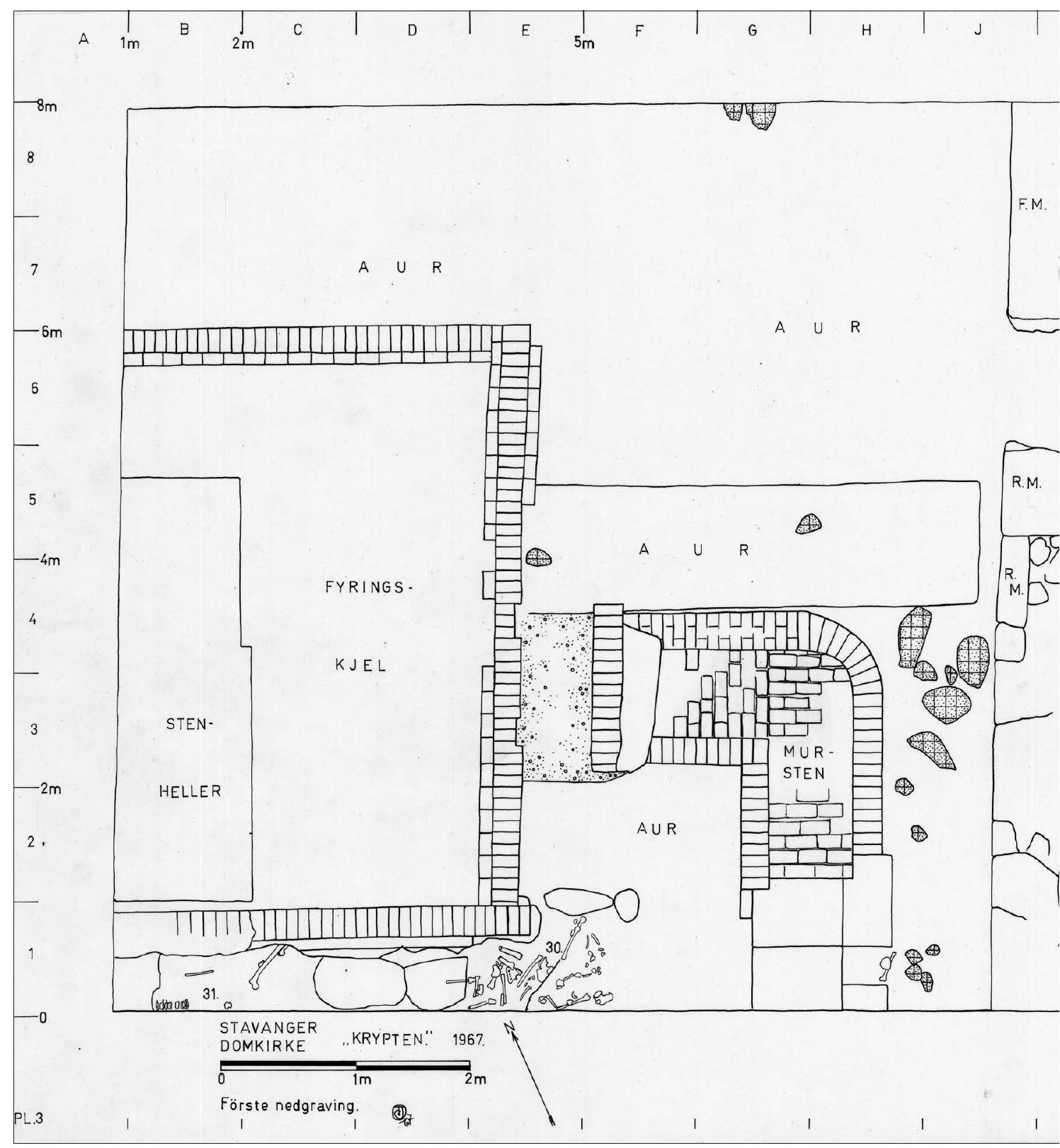

Figur 2. Stavanger domkyrkje. Første nivå i undersøkinga under koret med markering av nedgravingar for graver, fordelinga av skjelett og trekollag samt fyrkjel med luftekanal. Rom I på vestsida ved fyrkjelen, rom II på sørsida av midtmuren og rom III på nordsida. Figur: Perry Rolfsen/Torry Jøssang (1967). 


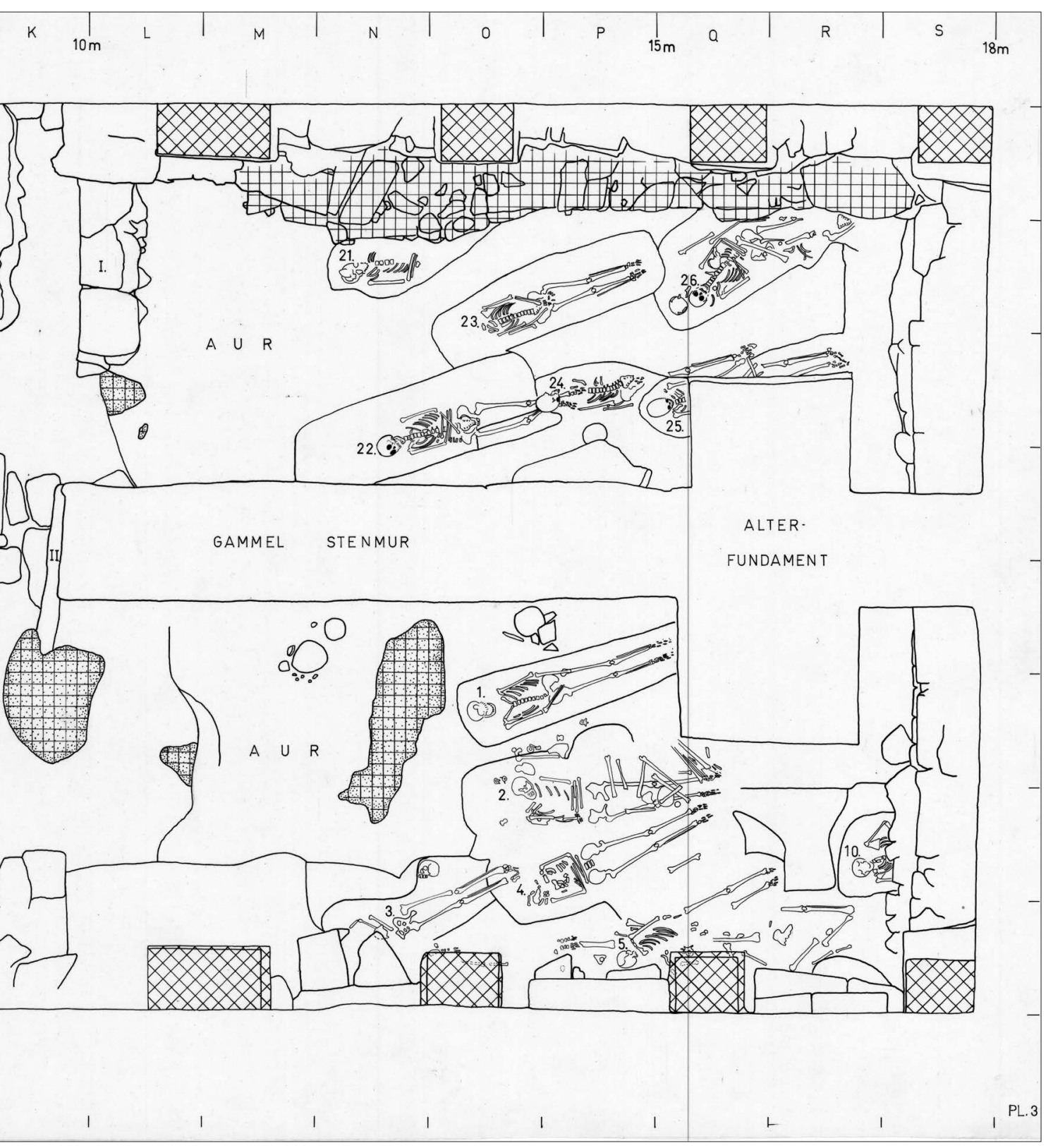




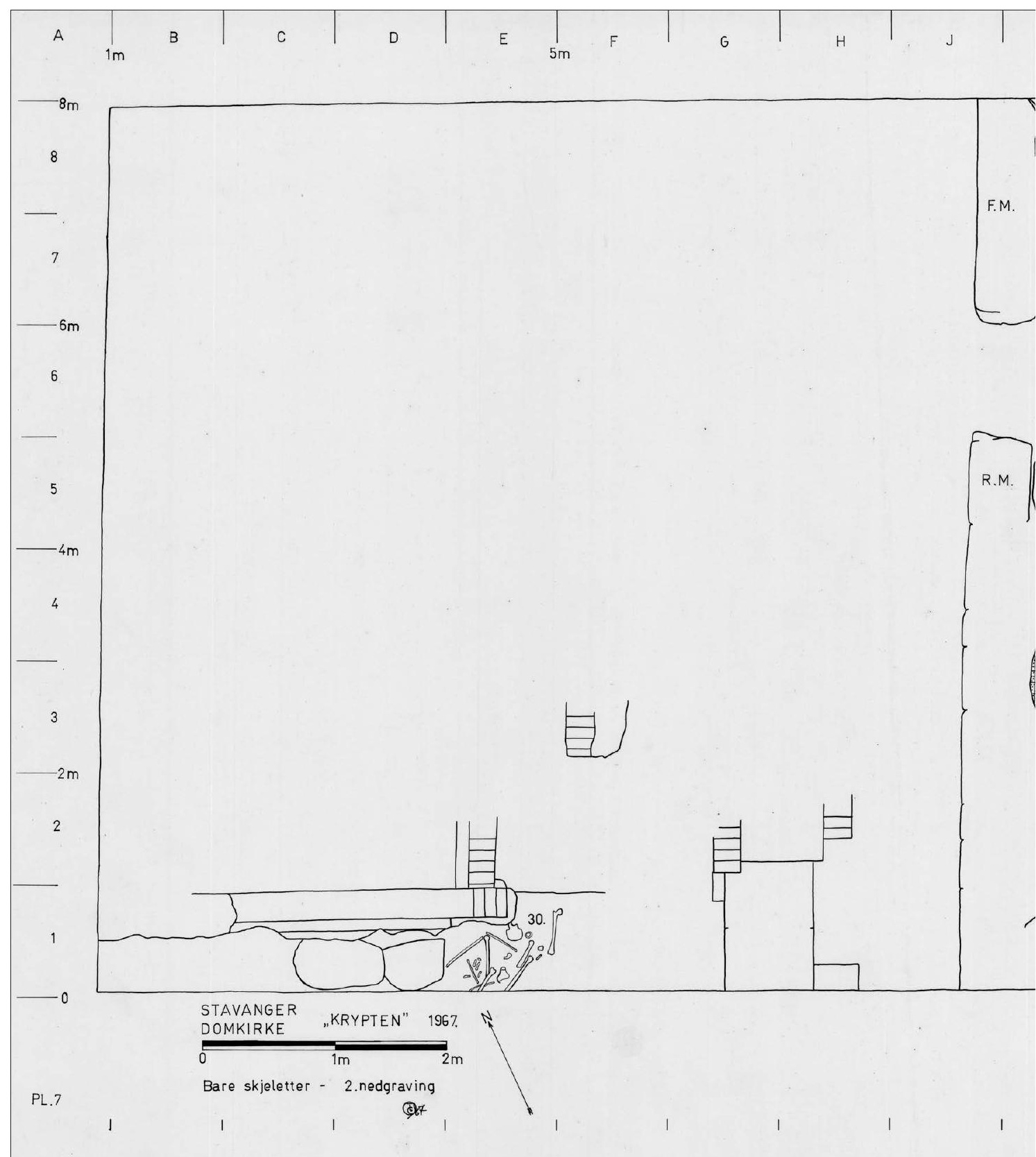

Figur 3. Stavanger domkyrkje. Andre nivå i undersøkinga under koret med markering av nedgravingar for graver, fordeling av skjelett og restar av trekollag samt fyrkjel med luftekanal. Rom I på vestsida ved fyrkjelen, rom II på sørsida av midtmuren og rom III på nordsida. Figur: Perry Rolfsen/Torry Jøssang (1967). 


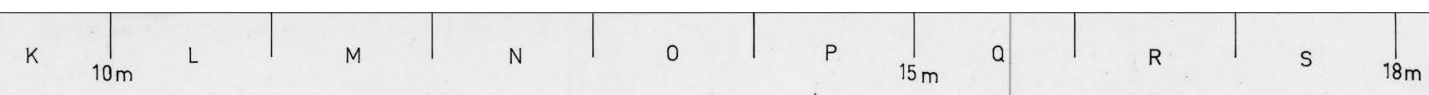

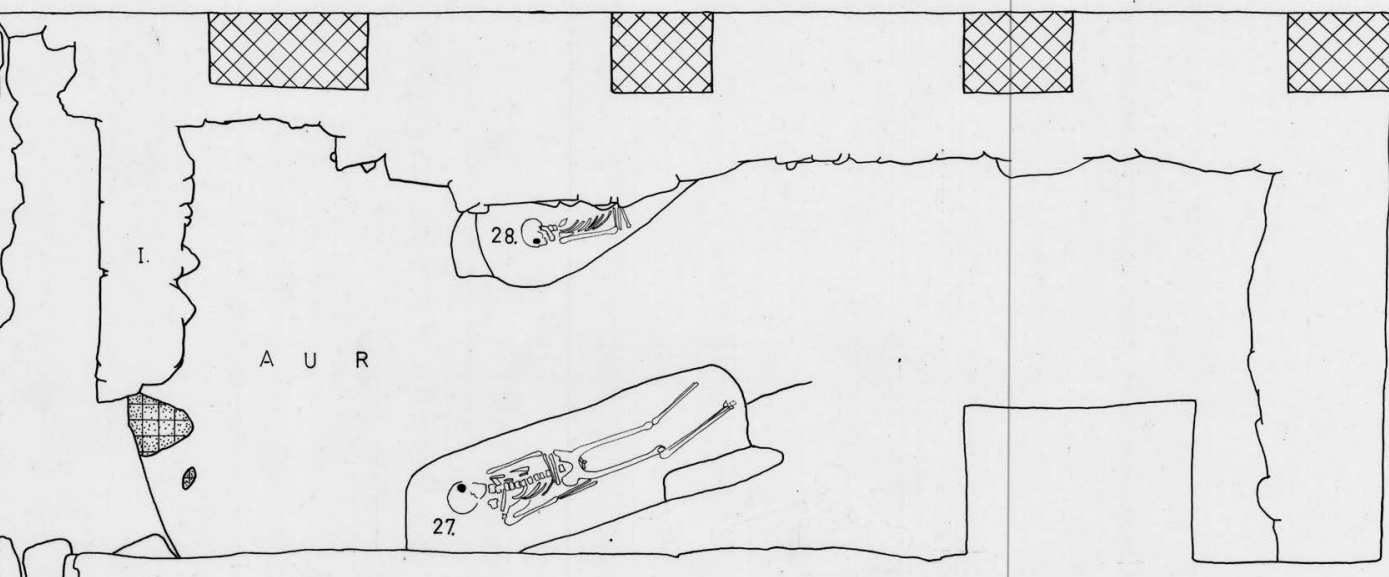

$\sqrt{1}$

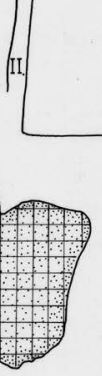

$\mathcal{1}$

GAMMEL STENMUR

ALTER-

FUNDAMENT

A $U$ R

2

PL.7 


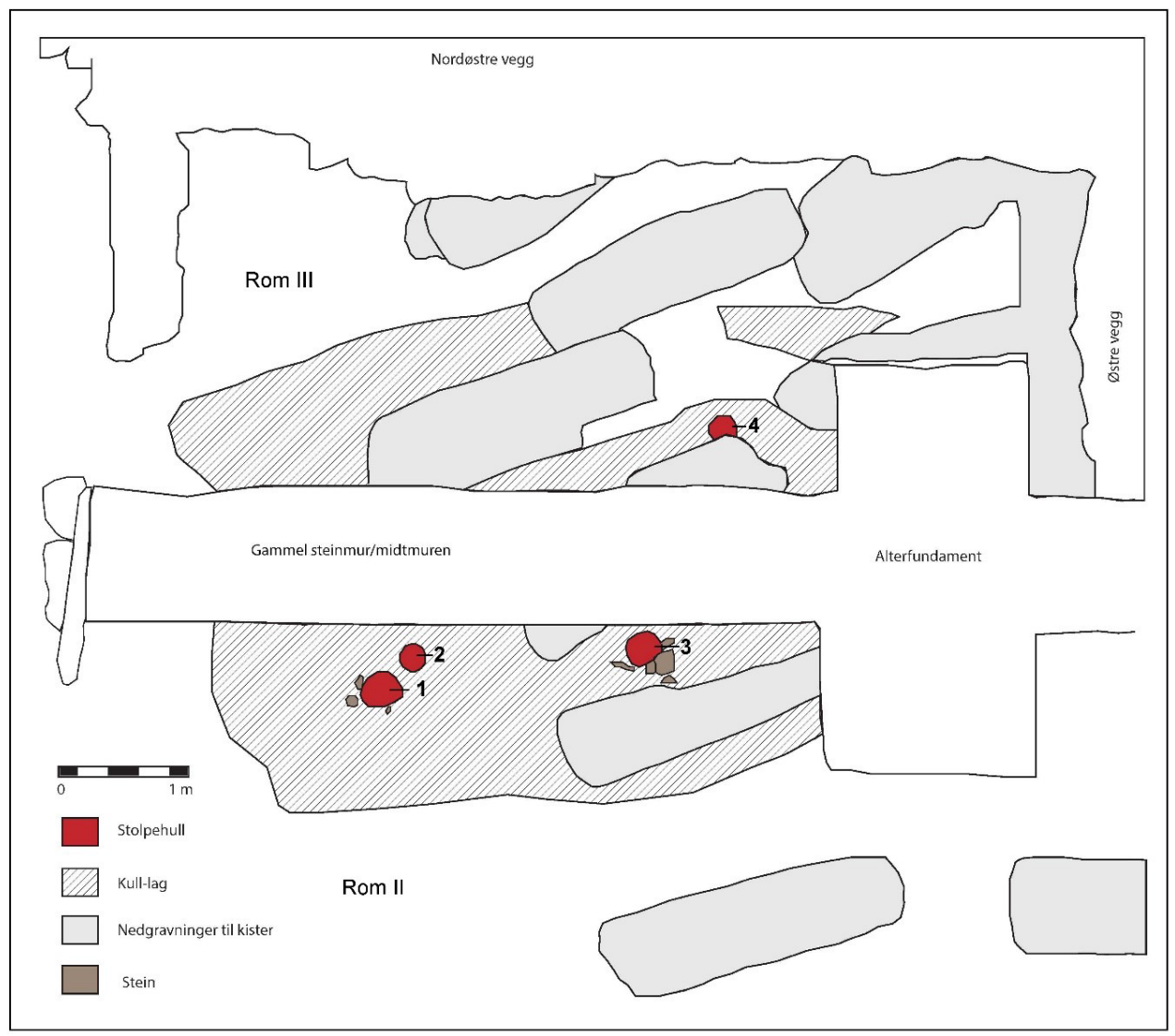

Figur 4. Rom II og III med markering av stolpehol, trekollag, alterfundament samt nedgravingar for kister. Forfattarane har sett inn nummerering av rom og stolpehol i figur frå Hilde Fyllingen og Wenche Brun (2017) på grunnlag av Perry Rolfsen/Torry Jøssang (1967).

av høg kvalitet samt ca. 350 foto i svart-kvitt, og alt dette finst i arkivet ved AM. Som figur 2, 3 og 5 syner, var skjeletta i generelt god stand, men meir eller mindre komplette då ein fann dei. Rolfsen laga ein innbyrdes stratigrafi mellom nokre av skjeletta der det var mogeleg, og på planteikninga er dei delt inn i to kategoriar: yngre skjelett (figur 2) og eldre skjelett (figur 3). Stratigrafiske forhold som det at skjeletta dels låg under murane, viser at dei må vere eldre enn kyrkja. Kollaget (figur 4) må vidare vere eldre enn dei gravene som kuttar gjennom det, og yngre eller omlag samtidig med stolpehola under. Grava for skjelett nr. 29, som ikkje er samla inn, kuttar som ein kan sjå av figur 4 ned i stolpehol 4, noko som er eitt døme på at stolpehola er eldre enn skjeletta. Kort summert er stratigrafien kring alterfundamentet frå det eldste til det yngste som følgjer: stolpehol, kollag, graver og skjelett, «kulturlag med gjenstandar og animalosteologisk materiale» eldre eller samtidig med skjeletta, og til slutt kyrkja som står i dag. 
Tabell 1: Skjelettdelar frå ulike skjelett samla inn under undersøkinga i 1967-68 i Stavanger domkyrkje. $x=$ påvist. Samanstilling etter Perry Rolfsen (1968).

\begin{tabular}{|c|c|c|c|c|c|c|c|c|c|c|c|c|c|c|c|c|}
\hline 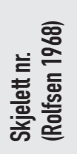 & 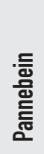 & 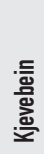 & 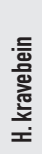 & $\begin{array}{l}\text { 등 } \\
\text { 离 } \\
\text { 离 } \\
\frac{1}{>}\end{array}$ & 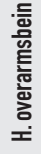 & 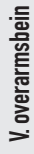 & 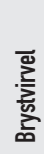 & $\begin{array}{l}\text { 듷 } \\
\text { 흏 } \\
\text { 흥 } \\
\text { x }\end{array}$ & $\begin{array}{l}\text { 듷 } \\
\text { 흥 } \\
\text { 흥 } \\
\text { ㅇ }\end{array}$ & 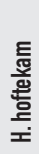 & $\begin{array}{l}\text { 틈 } \\
\text { 总 } \\
\text { 흥 } \\
\text { ․ }\end{array}$ & 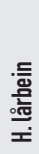 & & 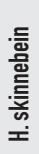 & 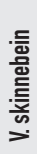 & $\begin{array}{l}\text { 등 } \\
\text { 产 }\end{array}$ \\
\hline 1 & $x$ & $x$ & $x$ & $x$ & $x$ & $x$ & $x$ & $x$ & $x$ & $x$ & $x$ & $x$ & $x$ & $x$ & $x$ & $x$ \\
\hline 2 & $x$ & $x$ & $x$ & & & $x$ & $x$ & $x$ & $x$ & $x$ & $x$ & $x$ & $x$ & $x$ & $x$ & $x$ \\
\hline 3 & & & & & & & & & & & & $x$ & $x$ & $x$ & $x$ & $x$ \\
\hline 4 & & & & & $x$ & $x$ & & $x$ & $x$ & $x$ & $x$ & $x$ & $x$ & $x$ & $x$ & $x$ \\
\hline 5 & $x$ & $x$ & & $x$ & & $x$ & & & & & & & $x$ & $x$ & $x$ & $x$ \\
\hline 6 & $x$ & $x$ & $x$ & $x$ & $x$ & $x$ & $x$ & $x$ & $x$ & $x$ & $x$ & $x$ & $x$ & $x$ & $x$ & $x$ \\
\hline 7 & $x$ & $x$ & $x$ & $x$ & & $x$ & $x$ & $x$ & $x$ & & $x$ & & $x$ & & $x$ & $x$ \\
\hline 8 & $x$ & $x$ & $x$ & $x$ & $x$ & $x$ & $x$ & & & & & & & & & \\
\hline 9 & $x$ & $x$ & $x$ & $x$ & & $x$ & $x$ & & $x$ & & & $x$ & $x$ & $x$ & $x$ & $x$ \\
\hline 10 & $x$ & $x$ & $x$ & $x$ & $x$ & $x$ & $x$ & & $x$ & & & & & & & \\
\hline 11 & & & & $x$ & $x$ & & $x$ & $x$ & & & & & $x$ & & & \\
\hline 12 & $x$ & $x$ & & $x$ & $x$ & $x$ & $x$ & & & & & & & & & \\
\hline 21 & $x$ & $x$ & $x$ & & $x$ & & $x$ & $x$ & & & & & & & & \\
\hline 22 & $x$ & $x$ & $x$ & $x$ & $x$ & $x$ & $x$ & $x$ & $x$ & $x$ & $x$ & $x$ & $x$ & $x$ & $x$ & $x$ \\
\hline 23 & & & & $x$ & $x$ & $x$ & $x$ & $x$ & $x$ & $x$ & $x$ & $x$ & $x$ & $x$ & $x$ & $x$ \\
\hline 24 & $x$ & $x$ & $x$ & $x$ & $x$ & & $x$ & $x$ & & $x$ & & $x$ & $x$ & $x$ & $x$ & $x$ \\
\hline 25 & $x$ & $x$ & $x$ & $x$ & $x$ & $x$ & $x$ & & & & & & $x$ & $x$ & $x$ & $x$ \\
\hline 26 & $x$ & $x$ & $x$ & $x$ & $x$ & $x$ & $x$ & $x$ & $x$ & $x$ & $x$ & $x$ & $x$ & & & \\
\hline 27 & $x$ & $x$ & $x$ & $x$ & $x$ & $x$ & $x$ & $x$ & $x$ & $x$ & $x$ & $x$ & $x$ & $x$ & $x$ & \\
\hline 28 & $x$ & $x$ & $x$ & & $x$ & & & $x$ & & & & & & & & \\
\hline 30 & & & & & & & $x$ & & & $x$ & $x$ & $x$ & $x$ & & & \\
\hline 31 & & $x$ & & & & & $x$ & $x$ & & & & $x$ & & $x$ & & \\
\hline
\end{tabular}




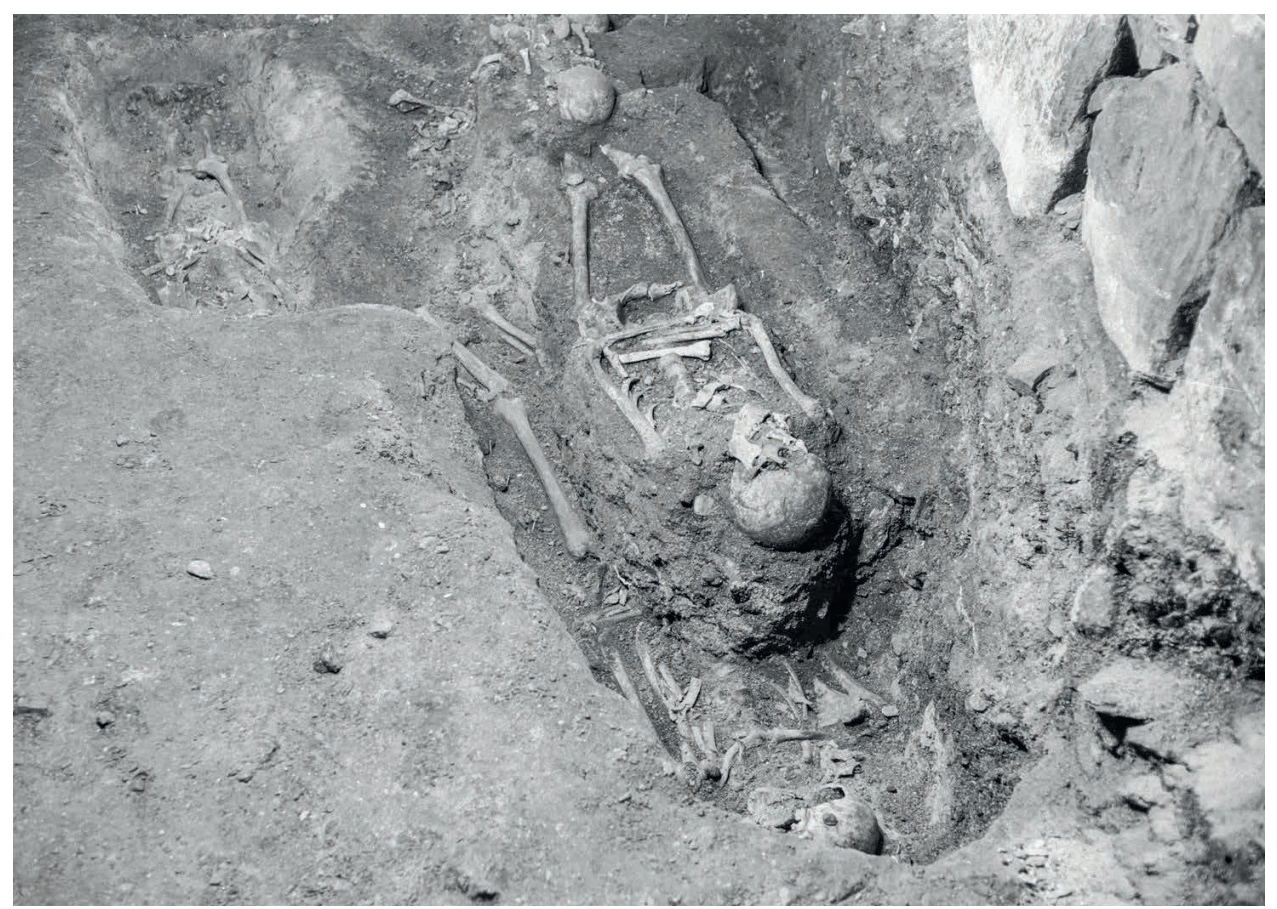

Figur 5. Stratigrafiske tilhøve mellom skjelett 23 til venstre, 22 i midten med beina under 24, djupast ligg skjelett 27. Foto: Perry Rolfsen/Svein Olav Larsen, AM, UiS (1968).

\section{Menneskeskjeletta: ex situ}

Beina vart reingjorte og pakka separat i medhald av rutinane for handsaming av funn ved AM. I februar 1968 vart i alt 22 skjelett fordelte på ni kasser samt ei liste som syner fordelinga av desse i kassene, ei kasse med lause bein samt planteikninga som syner plasseringa av gravene, sendt til De Schreinerske Samlinger ved Anatomisk institutt, Universitetet i Oslo, heretter nemnt DSS.

Johan Torgersen takka for sendinga som han ventar seg mykje av (brev datert 05.03.1968 til Odmund Møllerop i topografisk arkiv, AM, UiS). I eit brev til Perry Rolfsen, ansvarleg arkeolog for utgravinga, skriv Torgersen at materialet består av følgjande: «9 skaller og ekstremitetsknokler fra 10 individer, men samhørigheten mellom disse fremgår ikke». Vidare skriv han: «skallene er av 2 kvinner og 7 menn, og lårbenene av 3 kvinner og 7 menn» (udatert brev til Perry Rolfsen i topografisk arkiv, AM, UiS). At «samhørigheten mellom disse» ikkje går fram, er vanskeleg å forstå når ein ser lista over korleis skjeletta var merkte og pakka samt teikningar over plasseringa til skjeletta i utgravingsfeltet (figur 2 og 3). Kort fortalt ser det ut til at forklaringa på beinkassene er at alt ved opp-pakkinga i DSS vart skjeletta ikkje haldne samla, men ein tok ut beina ein ønskte å ha og returnerte resten til Stavanger.

Det som verkeleg er problematisk å forstå for oss, er at det så langt ikkje er funne brev eller anna skriftleg dokumentasjon i arkiva ved AM som kan kaste lys over årsaka til at det 
humanosteologiske materialet frå Domkyrkja vart delt opp på dette viset, og ikkje minst kvifor kassene med ein stor del av beina vart returnerte usortert (figur 1). Kva skulle og kunne AM gjera med innhaldet i beinkassene? Ingen hadde svar på dette spørsmålet, men det var klårt at beina ikkje kunne kasserast så kassene vart sett i magasinet, og her vart dei ståande. Dermed sluttar første avsnitt i denne soga.

\section{Analysane av materialet kjem i gang}

I 2004, i samband med oppstartinga av prosjektet «Tusenårsstedet Stavanger torg», hadde Stavanger kommune som tiltakshavar for prosjektet eit møte med AM som mellom anna resulterte i at kommunen løyvde midlar til fem C14-dateringar med formål å kaste nytt lys over alderen til Stavanger domkyrkje. Ein rekna med at det fanst material ved AM som var veleigna som dateringsprøver. Rapporten (Rolfsen 1968), samt mange teikningar og foto frå den arkeologiske utgravinga og ymse brevveksling i samband med denne fanst $i$ arkiva, medan materialet i magasinet bestod av ein del oldsaker av stein eller metall, mellom anna bronsenål, spelebrikke, del av skålvekt, perle, del av kam, bryner og spinnehjul (S9629). Nokon av desse er av typar som var i bruk over lang tid og som vanskeleg gjev ein eksakt datering, medan andre må vere frå mellomalder. I tillegg fants nokre prøver av trekol og jord - og beinkassene. Som figur 1 syner, var det nok bein å ta av i beinkassa, men i 2004 hadde ingen ved AM kompetanse til å vurdere desse for analytiske formål. Sidan nokre av skjeletta frå Stavanger domkyrkje var deponerte i DSS, kunne prøvemateriale til C14-dateringar hentast der. Ansvarleg for samlinga ved DSS tok ut prøver av korsbeinet (sacrum) frå to skjelett, høvesvis AI-nr. 5130 og 5132 (tabell 2).

\section{Dei første C14-dateringane}

C14-dateringar av skjelett frå Domkyrkja ville vere av stor interesse både for ålmenta og $\mathrm{AM}, \mathrm{og}$ det vart viktig å finne det best eigna prøvematerialet til desse. Nærare undersøkingar av jordprøver i magasinet ved AM, innsamla i 1968, påviste skal av hasselnøtter samt trekol av bjørk og uspesifisert lauvved som ikkje var av eik. Desse materialtypane, saman med prøvene av korsbeina, vart C14-datert i 2004-2005 ved Nasjonallaboratoriet for dateringer, NTNU. Dateringsresultata, alder BP (før no) inklusive to standardavvik, er rekna om til kalenderår etter kaliberering med OxCal v4.3.2 (Reimer mfl. 2013; Bronk Ramsey 2017), og alderane ligg innan tidsintervallet mellom ca. 700 og 1100 e.Kr. som det også går fram av figur 6. Resultata tyder på at trekolet (TUa-4609 og 4610) er eldre enn både skjeletta og hasselnøttskalet (TUa-4989 og 4990 og TUa-4611), og at alt datert materiale er eldre enn kyrkja (Sandvik 2006). Hendingane som er tidfesta med C14-dateringar er i samsvar med kronologien som Rolfsen foreslo i 1968; trekollaget var eldre enn skjeletta som var eldre enn kyrkja.

\section{Osteometrisk sortering}

Dateringsresultata førte sjølvsagt til at interessa for skjeletta auka, og AM engasjerte difor ein osteoarkeolog til arbeidet med å sortere og identifisere dei. Osteometrisk sortering er ein metodikk utvikla i samband med undersøkingar av massegraver og difor eit veleigna reiskap i arbeidet med å rekonstruere skjelett ut frå lause bein så som i kassa ved AM (sjå Denham 2014 for nærare omtale av metode og resultat). Beina i den største kassa vart ana- 
Tabell 2: Oversyn over skjelett frå De Schreinerske Samlinger samt frå kassa ved AM, UiS. Bestemmingane av alder, kjønn og høgd etter Denham 2014 (tabellane 1 og 5). Overskriftsrada syner kva type informasjon som står $i$ dei ulike kolonnane.

\begin{tabular}{|c|c|c|c|c|c|c|c|c|c|c|c|c|}
\hline 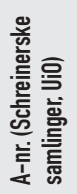 & 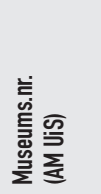 & 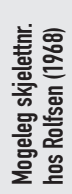 & 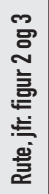 & 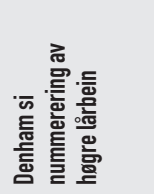 & 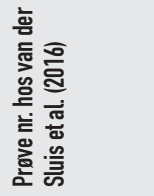 & 尝 & 言 & 몽 & 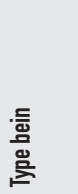 & 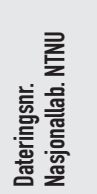 & $\begin{array}{l}\text { क } \\
\text { 竞 }\end{array}$ & 0 \\
\hline & & & & SD.1968.FE.R.1 & NO-STD-HB-21 & adult & mann? & & femur & TRa-1766 & 970 & 35 \\
\hline & 12810.404 & & & SD.1968.FE.R.2 & NO-STD-HB-29 & adult & mann & & femur & TRa-1767 & 995 & 35 \\
\hline & 12810.405 & 31 & B1 & SD.1968.FE.R.3 & NO-STD-HB-26 & adult & kvinne? & & femur & TRa-1768 & 990 & 35 \\
\hline \multirow[t]{4}{*}{5121} & 12810.286 & 4 & 01 & SD.1968.FE.R.4 & NO-STD-HB-23? & adult & mann & 178 & femur & TRa-1769 & 900 & 30 \\
\hline & 12810.290 & 24 & 06 & SD.1968.FE.R.5 & NO-STD-HB-24 & adult & mann & & femur & TRa-1770 & 1030 & 35 \\
\hline & 12810.406 & 30 & E1 & SD.1968.FE.R.6 & NO-STD-HB-27 & adult & kvinne? & & femur & TRa-1771 & 1255 & 35 \\
\hline & 12810.288 & 30 & E1 & SD.1968.FE.R.7 & NO-STD-HB-25 & adult & mann? & & femur & TRa-1772 & 930 & 30 \\
\hline \multirow[t]{2}{*}{5118} & 12810.292 & & & SD.1968.FE.R.8 & NO-STD-HB-28N & са. 20 & kvinne & 162 & femur & TRa-1773 & 915 & 35 \\
\hline & 12810.282 & 1 & 03 & SD.1968.FE.R.9 & NO-STD-HB-20 & $50-60$ & mann & & femur & TRa-1774 & 975 & 35 \\
\hline \multirow[t]{2}{*}{5115} & 12810.293 & 6 & Q2 & SD.1968.FE.R.10 & NO-STD-HB-22N & 20 & mann & 178 & femur & TRa-1775 & 985 & 35 \\
\hline & & & & SD.1968.FE.R.11 & NO-STD-HB-19 & adult & kvinne? & & femur & TRa-1776 & 1230 & 30 \\
\hline 5125 & $9629 a c$ & & & & & adult & mann & 170 & cranium & TRa-4448 & 945 & 25 \\
\hline 5126 & $9629 a c$ & & & & & $50-60$ & mann & 182 & cranium & TRa-4449 & 980 & 25 \\
\hline 5126 & $9629 a c$ & & & & & $50-60$ & mann & 182 & femur & TRa-4450 & 935 & 35 \\
\hline 5127 & $9629 a c$ & & & & & $50-60$ & U & 161 & cranium & TRa-4451 & 1025 & 30 \\
\hline 5128 & $9629 a c$ & & & & & adult & mann & 170 & femur & TRa-4452 & 1145 & 30 \\
\hline 5128 & $9629 a c$ & & & & & adult & mann & 170 & clav & TRa-4453 & 1105 & 30 \\
\hline 5129 & $9629 a c$ & & & & & adult & mann & 178 & femur & TRa-4454 & 1000 & 30 \\
\hline 5130 & $9629 a c$ & & & & & $50-60$ & kvinne & 162 & cranium & TRa-4455 & 1075 & 30 \\
\hline 5130 & $9629 a c$ & & & & & $50-60$ & kvinne & 162 & femur & TRa-4456 & 1085 & 30 \\
\hline 5130 & $9629 a c$ & & & & & $50-60$ & kvinne & 162 & sacrum & TUa-4989 & 1025 & 35 \\
\hline 5131 & $9629 a c$ & & & & & adult & U & n/a & cranium & TRa-4457 & 1135 & \\
\hline 5132 & $9629 a c$ & & & & & $50-60$ & U & 178 & sacrum & TUa-4990 & 1010 & 30 \\
\hline \multirow[t]{3}{*}{5133} & $9629 a c$ & & & & & adult & U & 188 & cranium & TRa-4458 & 1005 & 25 \\
\hline & 12810.296 & & & & & adult & mann & 176 & & & & \\
\hline & 12810.284 & & & & & adult & U & 164 & & & & \\
\hline
\end{tabular}




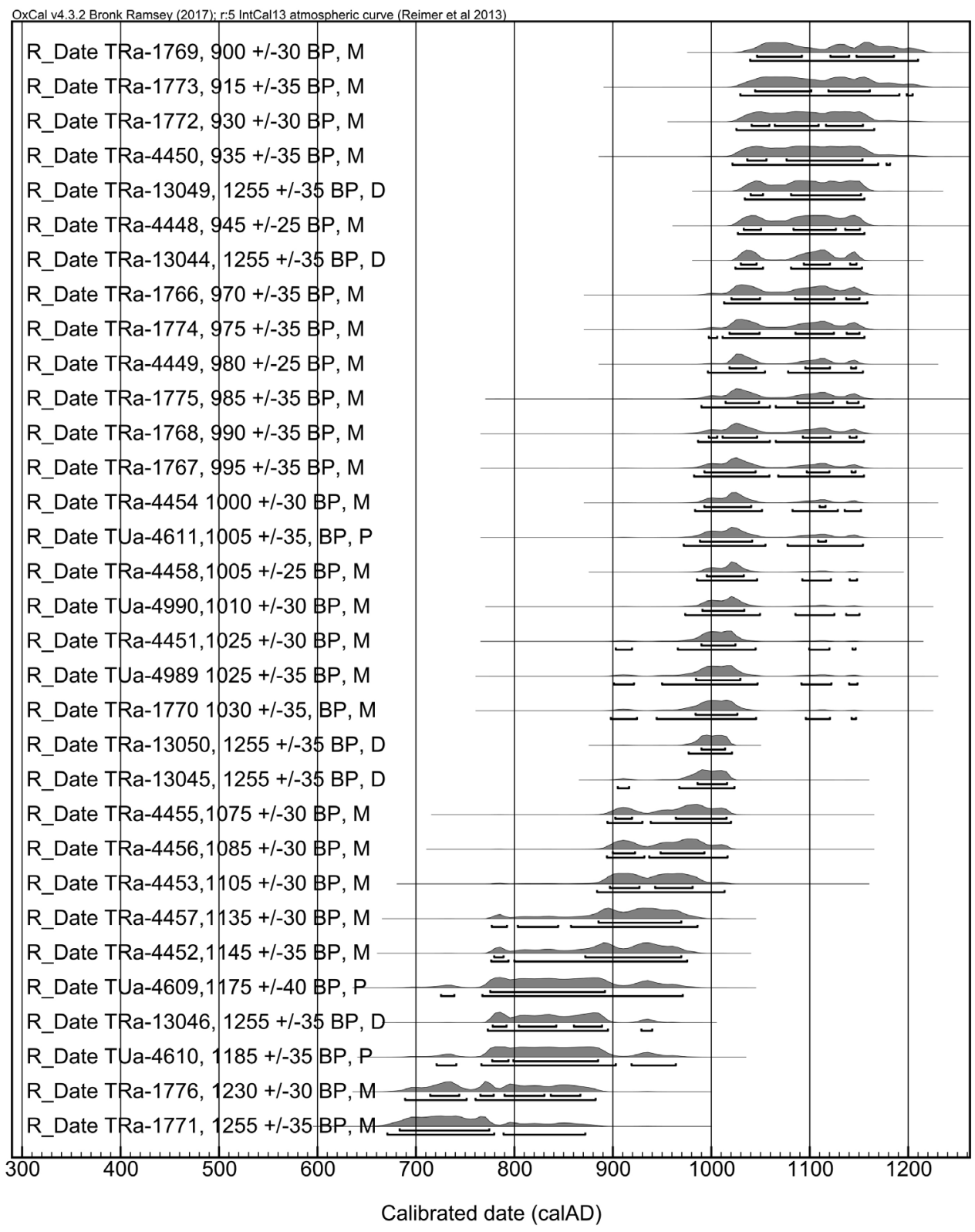

Figur 6. Resultat av alle C14-dateringar utført i tidsrommet 2005-2018 av høvesvis skjelett av menneske (M), bein av pattedyr (D) samt trekol og nøtteskal $(P)$ frå utgravinga under Stavanger domkyrkje i 1967-68. Frå venstre: dateringsnummer ved Nasjonallaboratoriet for dateringer, NTNU, alder BP (før no) med eit standardavvik, materialtype og til høgre plot som syner alder $i$ kalenderår etter kalibrering med OxCal4.3.2. av alder BP inklusive to standardavvik. Figur: Paula Utigard Sandvik. 
lyserte og ho inneheldt mellom 10000 og 20000 heile og fragmenterte bein som no har fått eit nytt museumsnummer, S12810 (sjå unimus.no/arkeologisøk). Av desse var det mogeleg for Denham å identifisere 1665 innanfor 387 undernummer. I tillegg påviste han 276 pattedyrbein, 50 fuglebein og 50 fiskebein i kassa, no fordelt på i alt 20 undernummer. Ut frå påskrift med Rolfsen sine skjelettnummer på papirlappar som satt på ein del av beina, kunne Denham klare å identifisere deler av fleire av skjeletta i beinkassa, høvesvis nr. 1, 2, 4, 6, 9, 23, 24, 30 og 31 (jf. tabell 1). I løpet av den osteologiske sorteringa fann Denham også bein med påskrivne nummer frå DSS som passa saman med bein med Rolfsen sine nummer, høvesvis 2 og 5114, 4 og 5121 samt 6 og 5115. (Beina i den minste kassa er enno ikkje tilstrekkeleg analyserte.) I følgje Rolfsen si gruppering høyrer 1, 2, 4, 23, 24 og 31 til dei yngre skjeletta (figur 2), 6 og 9 til dei eldre skjeletta (figur 3), medan 30 kan høyre til i begge gruppene. I tillegg kunne større deler av andre skjelett setjast saman, men utan at ein kunne knyte dei til særlege skjelettnummer. Denham klarte å setje saman deler av seks individ kor det var mogeleg å tolke kjønn, alder og kroppshøgd (Denham 2014:123:tabell 1). Tre høgre lårbein, FE.R. 1, FE.R. 2 og FE.R. 11 (tabell 2) kan truleg ikkje assosierast til noko andre av beina i beinkassa. Fleire bein kan dessutan relaterast til barn, men planteikningane viser ingen barneskjelett (figur 2 og 3 ) så det er mogeleg at desse kan stamme frå kassa med berre lause bein som AM sendte til DSS i 1968. Dessutan, på ein av planteikningane i arkivet på AM, er det merkt av store mengder lause bein.

\section{0 - fleire dateringsresultat}

Ein ønskte òg å datere fleire individ enn dei to som var daterte i 2005 (figur 6:TUa-4989 og 4990). For det vidare arbeidet var det viktig å ha kontroll på dei ulike individa til dateringar og eventuelle andre analysar som kunne vere av interesse i framtida. Dei høgre lårbeina (femur) som kvart representerer eitt individ vart prioriterte som prøvematerial, og det fanst elleve slike i den største beinkassa.

Nasjonallaboratoriet for dateringer, NTNU, utførte dateringane av lårbeina. I 2010 låg resultata føre, og kalibrert alder av desse inkl. 2 sigma synte aldrar innan tidsrommet ca. 680-1220 e.Kr. (figur 6:TRa-nr. 1766-1776). Desse nye dateringane støtta konklusjonen om at skjeletta er eldre enn kyrkja (Sandvik 2006). To av individa overraska med kalibrerte aldrar innan tidsrommet ca. 680-900 e.Kr (figur 6:TRa-1771 og 1776, tabell 2: FE.R. 6 og 11), noko som gav grunn til å stille spørsmål om desse kunne vere av dei eldste kristne gravene i Noreg.

\section{Histologiske analysar}

Histologiske analysar er nytta til å karakterisere mikrostrukturen i vev frå ulike livsformer, som i dette tilfellet er bein av menneske. Siktemålet med analysane er å kunne vurdere bevaringstilstanden i beinstrukturen, og kor vidt beina er eigna som prøver for ulike analysar. Analysane som vart utførte i samband med ein PhD-grad ved VU University i Amsterdam, var del av Leche-prosjektet, eit prosjekt som tok sikte på å studere om og korleis europearane endra seg etter kvart som mjølka kom inn i kosthaldet deira. Resultata synte at lårbeina frå beinkassa generelt hadde god nok bevaringstilstand til utnytting som prøver til ymse andre analysar (Hollund 2013). 


\section{Analysar av stabile isotop}

Beina til dyr og menneske er bygd opp av ymse grunnstoff som er tilførte frå maten. Det er utført analysar av stabile isotop av karbon (C), hydrogen $(\mathrm{H})$, nitrogen $(\mathrm{N})$ og svovel (S) i dei elleve daterte lårbeina som del av ein mastergrad, også ved VU University, Amsterdam (van der Sluis 2012). Desse resultata som er dei første i sitt slag frå stavangerområdet, gjev innsyn i kosthaldet i overgangen mellom vikingtid og mellomalder. I dette tidsrommet vart kristendommen innført, og med den kom krav om faste, dvs. tider av året utan kjøt og ymse andre matvarer, noko som påverka både matskikken til menneska og livsstilen reint generelt. Materialet er ikkje stort, og difor er det uråd å trekkje generelle slutningar. Det ser ut til at «forsøkspersonane» hadde eit rimeleg likt kosthald, men vi merker oss også med stor interesse at tilhøvet mellom dei målte isotopverdiane hos dei to eldste individa tyder på at desse to hadde eit kosthald med større bidrag frå terrestriske enn marine kjelde, samanlikna med kva som er tilfelle hos alle dei yngre skjeletta (van der Sluis mfl. 2016:123; figur 6:TRa-1771 og 1776). Eit av desse eldste individa, TRa-1776, var representert berre med høgre lårbein, medan det andre, TRa-1771, i fylgje Denham (www.unimus.no/arkeologisøk; S12810.406) mogelegvis kan assosierast med ei beinsamling kalla skjelett 30 (Rolfsen 1968; sjå figur 2). Denham (sjå tabell 2) har tolka begge til mest truleg å vere av vaksne kvinner. Som omtala tidlegare speglar isotopverdiane mennesket sine levekår. Var kosthaldet generelt annleis i tidsrommet ca. 680-900 e.Kr. enn seinare, var kvinnene innflyttarar til Rogaland frå område med andre matvanar, var dei i slekt? Resultatet av dateringane og isotopanalysane saman reiser mange spørsmål som vi enno ikkje kan svare på.

\section{Undersøkingar av skjeletta i De Schreinerske Samlinger}

I 2012 gjekk Denham gjennom skjelettmaterialet i DSS (Denham 2012), noko som gav eit anna resultat enn kva Torgersen gjorde greie for (udatert brev til Perry Rolfsen i topografisk arkiv, AM, UiS). I følgje Torgersen var det bein av sju menn og to eller tre kvinner, medan Denham kom fram til at det er bein av ei kvinne, fire menn samt fire som han ikkje kunne fastslå kjønnet på (Denham 2014:132:tabell 5). Verd å merke seg er at fire av individa er mellom 50 og 60 år, medan fem er innanfor kategorien adult, og kroppshøgda deira varierer mellom 161 og $188 \mathrm{~cm}$.

I 2012 vart det utført fleire dateringar av skjeletta som no er deponerte i DSS. Ansvarlege for samlingane i DSS valde ut prøvene til i alt elleve dateringar i 2012 (figur 6:TRa4448-4458). AM ønskte å halda fram med å datere høgre lårbein for å sikre kunnskap om fleire ulike individ, men det fanst berre tre slike i DSS så ein supplerte med prøver av kranier (cranium) og i eitt tilfelle av kragebein (clavicula). Verd å merke seg er at alle nye dateringar frå DSS ligg innan tidsrommet 900 til 1000 e.Kr.

\section{8 - Dateringar av dyrebein}

Ein samla òg inn bein av pattedyr, fugl og fisk (museumsnummer S9629ad) under utgravinga i 1967-68 og sende desse til Zoologisk Museum, Universitetet i Bergen. Haakon Olsen identifiserte 708 av i alt 1022 fragment til art, slekt eller familie (J.S. 493). Som rapporten syner (Olsen 1968), stamma beina frå ei rekkje ulike typar av pattedyr, fugl og fisk. Av pattedyr var det ville dyr både frå sjø og land, høvesvis steinkobbe og hare, husdyr som svin, storfe, sau og geit som alle er veleigna til mat samt bein av katt og gnagarar. Av fuglebeina var det høvesvis ærfugl, lirype, høns og klippedue, artar som alle er gode matvarer, 
samt krykkje og fiskemåke som i alle fall i notid synes mindre attraktive som mat. I tillegg fanst bein av gode matfiskar så som pigghå, laks, torsk, lyr, sei, brosme, lange og makrell. Nokre av beina er av artar kjende som gode matressursar, medan andre er tilknytt busetnad. Dersom desse var av same alder som skjeletta, kunne dei gje oss innsyn i kosthaldet deira. Dersom dei var eldre enn menneska, kunne dei vera avsette frå ein busetnad på staden $f ø r$ gravplassen vart etablert. Difor vart eit lite utval av pattedyrbein, høvesvis storfe, gris og katt, datert i 2018 (figur 6:TRa-13044-13046 og 13049-13050). Dateringsresultata har vist at desse dyra levde innan ca. 900 og 1150 e.Kr., det same tidsrommet som fleirtalet av menneska frå gravene.

\section{Status for analytiske resultat}

Det ligg no føre i alt 32 C14-dateringar som tidfestar ymse materialtypar, avsett på staden der Stavanger domkyrkje vart reist i første halvdel av 1100-talet. Alle C14-dateringane som er utførte hittil, og prøvematerialet til desse, er presenterte i kronologisk rekkefølgje i figur 6. Fleirtalet av dateringane, 24 i alt, er av menneske, og som figur 6 syner, levde desse i tidsrommet som kan strekkje seg frå ca. 680 til 1220 e.Kr. To av individa er daterte til mellom ca. 680 og 900 e.Kr., noko som er ein uventa høg alder til å vere frå kristne graver i Noreg. Fleirtalet av dateringane ligg innanfor tidsrommet mellom 900 og 1100 e.Kr. Som figur 6 viser, famnar to av dei, høvesvis TRa-1769 og TRa-1773, tida frå første del av 1000-talet fram til ca. 1200 e.Kr. og dermed både før og etter at kyrkja vart reist. Gravene undersøkt i 1968 var alle frå under den delen av kyrkja som vart reist då ein utvida koret etter ein brann sist på 1200-talet. Orienteringa i høve til kyrkja er lik for alle gravene (figur 2 og 3), noko som tyder på at alle er frå tida før reisinga av kyrkja starta, og at alderen deira difor kan setjast til første del av 1100-talet eller tidlegare.

Isotopanalysane gjev innsyn i levekåra til dei elleve individa som var representerte med høgre lårbein frå beinkassa, medan korkje slike analysar eller histologiske analysar hittil er utførte på prøvene av skjelett frå DSS eller frå den minste beinkassa.

\section{Uklår proveniens og andre feilkjelder}

Beinkassa ved AM med sitt innhald reiser fleire spørsmål og problem som er viktige ikkje berre for AM, men for alle som samlar inn, kuraterar eller ønskjer å utnytte skjelett i si forsking. Difor kan det vere på sin plass å gjera greie for nokre av dei problema som har dukka opp i samband med undersøkingane av skjeletta frå 1968, både dei som finst i beinkassene ved AM og i samlinga ved DSS.

Først, Rolfsen sine 22 skjelettnummer frå primærdokumentasjonen (figur 2 og 3, tabell 1) er ikkje relaterte til DSS sine arkivnummmer. Dinest, i brevet Torgersen sende Rolfsen (udatert brev til Perry Rolfsen i topografisk arkiv, AM, UiS), er det tale om «9 skaller» og «ekstremitetsknokler av 10 individer» og vidare «lårben av 3 kvinner og 7 menn» som i DSS har fått AI-nr. 5125-5133, altså ni og ikkje ti som talet på lårbein skulle tyde på. Ein gjennomgang av skjelettmaterialet frå Stavanger domkyrkje i DSS (Denham 2012) syner at dei beheldt fleire bein enn kva Torgersen opplyste i ovannemnde brev (sjå tabell 3). Det mest problematiske er likevel at AM hadde rekna med at alt innhald i beinkassene var samla inn ved utgravinga under Stavanger domkyrkje i 1967-68, men då innhaldet i den største kassa vart nærare inspisert ca. 40 år seinare, og etter at fleire av analysane av dei elleve høgre lårbein frå kassa var gjennomførte, meldte tvilen seg. I beinkassene fanst òg bein eller lap- 
Tabell 3: Skjelettdelar i De Schreinerske Samlinger frå skjelett frå undersøkinga i 1967-68 i Stavanger domkyrkje. $x=$ påvist. Samanstilling etter Sean Dexter Denham (2012).

\begin{tabular}{|c|c|c|c|c|c|c|c|c|c|c|c|c|c|c|c|c|c|c|c|}
\hline 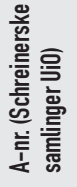 & 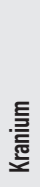 & 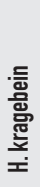 & 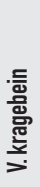 & 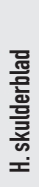 & 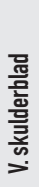 & 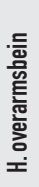 & 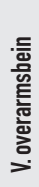 & 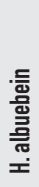 & 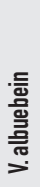 & $\begin{array}{l}\text { 등 } \\
\text { 흥 } \\
\text { 응 } \\
\text { ㅍ }\end{array}$ & $\begin{array}{l}\text { 등 } \\
\text { 융 } \\
\text { 응 } \\
\Rightarrow\end{array}$ & 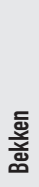 & $\begin{array}{l}\text { 등 } \\
\text { 을 } \\
\text { 흐 }\end{array}$ & 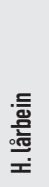 & 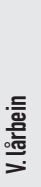 & 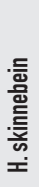 & 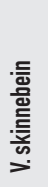 & 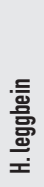 & 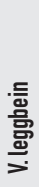 \\
\hline 5125 & $x$ & $x$ & $x$ & & & $x$ & & & & & $x$ & & & & & & & & \\
\hline 5126 & $x$ & $x$ & & $x$ & $x$ & & & & $x$ & & & $x$ & $x$ & $x$ & $x$ & & $x$ & & $x$ \\
\hline 5127 & $x$ & & & & & & $x$ & $x$ & $x$ & & $x$ & $x$ & & & & & & & \\
\hline 5128 & $x$ & & $x$ & & & & & & & & $x$ & & $x$ & $x$ & $x$ & & $x$ & & \\
\hline 5129 & $x$ & & $x$ & & & & & & & & & & & & & $x$ & $x$ & $x$ & \\
\hline 5130 & $x$ & & & & & $x$ & $x$ & & $x$ & & $x$ & $x$ & $x$ & $x$ & $x$ & $x$ & $x$ & & $x$ \\
\hline 5131 & $x$ & & & & & & & & & & & & & & & & & & \\
\hline 5132 & $x$ & $x$ & $x$ & & & $x$ & $x$ & X & $x$ & $x$ & $x$ & & $x$ & & $x$ & & & & \\
\hline 5133 & $x$ & $x$ & & & & $x$ & & & & & & & & & & & & & \\
\hline
\end{tabular}

par merkte med AI-nummer 5113-5124 og 5134, altså 13 ulike AI-nummer som i følgje DSS sitt arkiv ikkje høyrer til funna frå domkyrkja, men er frå høvesvis Mære kyrkje, Steinkjer k., Trøndelag, ymse lokalitetar i Nordland, Troms, Finnmark, på Jan Mayen og Mariakyrkja i Oslo. Ut frå AI-numra i arkivet ved DSS er det difor mogeleg at tre av dei C14-daterte og analyserte høgre lårbeina frå kassa ved AM, er frå Nord-Noreg. AI-nr. 5115 skal vere frå ein lokalitet med tre raserte båtgraver. Lårbeinet (TUa-1775) som er datert til mellomalder, er av Denham (2014:123:S12810.293, sjå òg tabell 2) bestemt å vere frå ein 20 år gamal mann. Då det mannlege individet frå ei av båtgravene i tillegg skal vere mellom 40 og 50 år, synes det lite truleg at det daterte lårbeinet til mellomalder stammer frå ovannemnde lokalitet. Dei to andre lokalitetane (AI-nr. 5118 og AI-nr. 5121) skal vere samiske med respektive fire og eitt individ. Dateringane til mellomalder (Tua-1773 og Tua-1769) kan stemme med dei kontekstuelle tilhøva, samstundes er det noko som skurrar då den mogelegvis samiske mannen frå sistnemnde lokalitet skal vere ein 50 år gamal mann (AI-nr. 5121), medan lårbeinet av Denham (2014:123:S12810.286, sjå òg tabell 2) er bestemt til kategorien adult.

Vidare, nokre av beina frå Stavanger i DSS har AI-nummer som først er skrivne med raudt blekk, og deretter er skrivne over med svart. Der tala under er leselege, er dei annleis enn dei over. Kan årsaka vere at ein først har merka beina med eitt AI-nr., og at numra i DDS seinare vart endra utan at numra på beina som alt var sendt attende til AM, vart retta opp? Eit døme på at dette kan vere tilfelle, gjeld eitt bein merka 5114 som fanst i beinkassa. I følgje arkivet i DSS er AI-nr. 5114 frå Gamvik i Finnmark. Sellevold (1991) omtalar dette funnet, med Povl Simonsen som kjelde, som frå ei pomorgrav. Ved bruk av osteometrisk 
sortering klarte Denham å finne 33 andre skjelettdelar (67 fragment) som høyrde saman med dette (www.unimus.no/arkeologisøk S12810.294), mellom anna både høgre og venstre skulderblad. Ein gjennomgang av bein i DSS i 1991 viste at begge skulderblada til AI-5114 då fanst der (Sellevold 1991). Ingen menneske er utstyrt med doble sett skulderblad, og opplysningane vi finn, tyder at det i dette tilfellet kan vera tale om ei feilmerking. Dessutan, i den minste beinkassa låg ein lapp kor det sto 5113, 5114, 5115 osv. AI-nr. 5113 er skjelett frå Mære kyrkje, kor Holck publiserte resultata i 1970 (Holck 1970), og det er tvilsamt at bein frå denne gravinga vart lagde i beinkassene. Verd å merke seg er òg at nummerrekka går frå AI-nr. 5113 til 5134, dvs. 22 nummer, noko som stemmer med talet på skjelett som AM sende til DSS i 1968. Vidare, om ein legg saman ulike skjelettdelar som er i dei to kassene med materialet som finst i DSS, er talet på individ nokså sams med det ein kan forvente vart sendt til DSS (munnleg opplysning Sean Dexter Denham).

Dette, saman med det faktum at isotopverdiane av dei tre lårbeina som kan vere frå NordNoreg ikkje skil seg frå dei andre beina med lik datering, gjer det særs sannsynleg at beina i beinkassa verkeleg stammer frå Domkyrkja. Dette kan understøttas av resultata frå analysar av høvesvis ymse dyrebein (Olsen 1968) og botanisk materiale (Sandvik 2006) som heilt sikkert stammer frå undersøkingane under Stavanger domkyrkje i 1967-68, og som gav dateringar innan same tidsrom som skjeletta. Dersom vi i framhaldet føreset at det er slik, får vi eit vidare grunnlag for å vurdere innhaldet $\mathrm{i}$ beinkassene i samanheng med historia om Stavanger.

Men først vil vi knyte nokre betraktningar om det å nytte eit material til forsking som rett nok har vore innsamla og dokumentert på ein framifrå og respektfull måte, men har, pga. uheldige omstende og den gong manglande etiske retningsliner for forvaltning av leivningar etter menneskje, vore særs utfordrande. No trur vi dette er eit spesielt døme, men det syner kan hende at forskjellige fag har hatt ulike innfallsvinklar til materialet; medisinarane var mest opptekne av skjelettet i seg sjølv (og særleg då kraniet og ekstremitetsknoklar), medan arkeologane var og er opptekne av kontekst. Undersøkinga i Stavanger domkyrkje, og den vidare handsaminga, kan òg vere ein vekker for dagens forvaltning. Innsamling, prioriteringar og kassasjon må skje etter etiske retningslinjer, vere framtidsretta og gjennomdiskutert, òg når det gjeld naturvitskapeleg material. Eksempelet kan vidare tene som ei påminning til alle som arbeider med organisk material, egna til avansert analytisk metodikk, om kor farefull vegen frå jord til magasin og vidare til forsking kan vere.

\section{Ny kunnskap om byhistoria i Stavanger?}

Utgangspunktet for arbeidet vi presenterer er to kasser som inneheldt lause skjelettdelar samla inn i 1967-68 under ei utgraving i Stavanger domkyrkje. Utgravinga er vel dokumentert i ein rapport (Rolfsen 1968), av foto, teikningar og tabellar samt funnmaterialet som finst i høvesvis topografisk arkiv og magasinet ved AM, UiS. Oversendinga av innsamla skjelettmateriale til DSS, UiO, og stadfesting av mottak der, er også dokumentert. Deretter blir den skriftleg dokumentasjon mangelfull, medan fysiske restar i form av ei stor og ei mindre kasse med bein frå DSS som vart leverte til museet på eit ukjent tidspunkt, finst.

Ymse undersøkingar, utført på materiale frå utgravinga i Domkyrkja, kom likevel i gang i 2004 (Sandvik 2006), og resultata inspirerte til vidare satsing på å finne ut meir om beina i kassene og lagnaden til desse menneska. Resultata hittil har gjeve ny kunnskap om ein del 
menneske frå fortida og deira levekår. C14-dateringar som no er utførte tyder på at desse levde i tidsrommet frå ca. 680 til 1250 e.Kr. (cal 2 sigma), medan dateringsresultata, desse sett saman med orienteringa av gravene i høve til kyrkja. tyder på at det heller er tale om ca. 680 til 1150 e.Kr. To av dateringane skil seg ut ved å vere klårt eldre enn dei andre (figur 6, TRa-1771 og TRa-1776, tabell 2). FE.R. 6 kan mogelegvis assosierast med skjelett nr. 30 (som låg hulter til bulter), mens FE.R. 11 ikkje kunne knytes til nokon av dei skjeletta som Denham satt saman ved hjelp av osteometrisk sortering (Denham 2014). Spesialistar ved Nasjonallaboratoriet for dateringer, NTNU, som har vurdert desse to dateringane for oss, konkluderer at ut frå gjeldande kalibreringskurve (Reimer mfl. 2013) kan ein innan 95,4 \% ikkje koma nærare i alder enn 686 til 872 e.Kr. Desse beina kan stamme frå heidenske graver på staden som ein seinare tok i bruk til ein kristen gravplass, eller frå menneske i Stavanger som har fått ein svært tidleg kristen gravlegging. Med atterhald om endringar i gravskikk, mellom anna kven i samfunnet som fekk ein synleg gravlegging, kan talet på graver frå respektive eldre og yngre jarnalder òg indikere at kristendomen fekk tidleg innpass i Rogaland. Frå eldre jarnalder finst om lag dobbelt så mange graver som frå yngre jarnalder (Denham mfl. 2018).

Osteometrisk sortering av beina har kunne kopla delar av skjelett og dermed gje kunnskap om kjønnsfordeling, alder og kroppshøgd til nokre av dei gravlagde (Denham 2014, sjå òg tabell 2). Resultata av isotopanalysane (van der Sluis 2012; van der Sluis mfl. 2016) gjev innsyn i kosthaldet, noko som kan tyde på ei endring mot meir mat frå marine kjelder i mellomalderen enn tidlegare periodar. Som kjend medførte kristendommen fastedagar utan kjøt i kosten, noko som kan ha påverka isotopverdiane i skjeletta.

Lausmassane kring gravene inneheldt både gjenstandar og animalosteologisk materiale (som viser eit variert kosthald), altså avfall, noko som tyder på at ein har henta materiale til oppfylling av gravplassen frå avfallshaugar i og kring busetnad i nærleiken. Kattebein frå djup på 0,2 og 0,6 m er daterte til høvesvis til 780-900 e.Kr. (TRa-13046) og 980-1020 e.Kr. (TRa-13050), og det at det eldste ligg over det yngste støttar opp om at materialet er redeponert. Eit kollag som dekte eit avgrensa område inne i kyrkja (figur 4) er spor etter ein brann 800 til 900 e.Kr. Under trekollaget fanst det fire stolpehol, noko som kan tyde på at trekolet skriv seg frå ei bygning som sto på høgda der Domkyrkja står i dag. Denne er ein av dei eldste bygningane som til no er påvist i Stavanger. Fleire graver som kuttar gjennom trekollaget, viser til gravleggingar etter brannen. Alle desse hendingane er eldre enn Domkyrkja. Alt i alt støtter funna opp om det synspunktet at Stavanger hadde ein etablert busetnad før bispesetet var etablert og Domkyrkja bygd.

I tida mellom 2004 og 2014 har det vore fleire undersøkingar i den eldste delen av bygrunnen i Stavanger (Sandvik 2006; Denham 2012; van der Sluis 2012; Denham mfl. 2013; Hollund 2013; Sandvik 2013; Denham 2014; van der Sluis mfl. 2016; Reed 2016; Sandvik 2020), og resultata frå desse gjev innsyn i tilhøva på staden både før og etter etableringa av bispesetet og bygginga av Stavanger domkyrkje i første halvdel av 1100-talet. Om byen først vaks fram etter etableringa av bispesetet, eller om det alt fanst ein etablert busetnad på staden, har vore gjenstand for diskusjonar (sjå Brendalsmo og Paasche 2017). Mellom anna på bakgrunn av desse og tidlegare undersøkingar samt undersøkingane av skjeletta frå Domkyrkja meiner Brendalsmo og Paasche (2017) at mykje tyder på at Stavanger før etableringa av bispesetet var noko meir enn ein vanleg gard i vikingtid og tidleg mellomalder. Dei foreslår at det her kan ha vore anløps- og utvekslingsstad, at staden 
hadde knutepunktfunksjonar som tingplass samt var samlingsstad for leidangsskip frå minst tre skipreider. Gravplassen under Domkyrkja, kor både kvinner, menn og barn var gravlagde, tyder på eit etablert samfunn kor kristendommen alt hadde fått innpass, noko som støtter opp om denne tolkinga.

Som det går fram, har arbeidet gått over mange år, men med noko ujamn innsats. Kronologien går attende til 2004 då dei første C14-dateringane vart utførte i eit samarbeid mellom Stavanger kommune, AM og DSS. Dateringsresultata saman med innsynet i arkivalia ved AM resulterte i mange spørsmål. I 2010 vart det oppretta eit programområde for forsking ved UiS kor det vidare arbeidet med skjelettmaterialet vart ein viktig del. Dette vart vidareført i eit nytt programområde som starta i 2014. Undersøkingane hittil har gjeve både interessante resultat og nye spørsmål som vi førebels ikkje kan svare på, mellom anna slektskapet mellom dei gravlagde individa. Frå og med 2020 er det i gang eit nytt forskingsprosjekt ved AM, UiS, med løyving frå NFR FRIPRO for Yngre forskertalenter. Prosjektet har tittelen «Future preservation of past life: A multidisciplinary investigation into preservation of ancient biological remains from medieval cemeteries» (NRF 2019) med Hege Ingjerd Hollund, AM, som prosjektleiar. Dette er eit prosjekt som tek føre seg biologiske leivningar som kan fortelje om livet i mellomalderen - og som skal sjå nærare på mellomalderskjelett og graver i Stavanger domkyrkje og elles i Rogaland.

Siste ord om skjelett frå Stavanger er ikkje skrive!

\section{Takk}

Takk til samarbeidspartnarane våre gjennom åra: professor emeritus Per Holck for all bistand og hjelp i De Schreinerske Samlinger, Sean D. Denham, Hege I. Hollund, Mads Ravn og Laura van der Sluis for framifrå samarbeid gjennom ymse programområde for forsking ved UiS, Ingund Svendsen, AM, for hjelp med grafikk og Marie-Joseé Nadeau og Martin Seiler, Nasjonallaboratoriet for dateringer, NTNU, for hjelp med kalibrering av C14-dateringar. Sist, men ikkje minst takkar vi Elise Naumann og ein anonym referee for konstruktive merknader og gode råd.

\section{Litteratur}

Brendalsmo, Jan og Knut Paasche

2017 Stavanger - før det ble en by. Historisk tidsskrift. Bind 96, s. 103-123.

Bronk Ramsey, Christopher

2017 OxCal v4.3.2. Elektronisk dokument, http://c14.arch.ox.ac.uk, besøkt 1.3.2018.

Denham, Sean Dexter

2012 Registrering av skjelett 5125 til 5133 fra Stavanger domkirke i De Schreinerske samlinger.

Rapport. Topografisk arkiv, Arkeologisk museum, UiS.

2014 Commingled Human Remains from Stavanger Cathedral. I Old Bones. Osteoarchaeology in Norway: Yesterday, Today and Tomorrow, redigert av Berit Jansen Sellevold, s. 117-136. Novus Forlag.

Denham, Sean Dexter, Hege Ingjerd Hollund og Laura van der Sluis

2013 Bevarte skjelett som arkiv for levde liv. Nye metodar for undersøkingar av beinmateriale frå Domkyrkja. I Stavangeren. Tidsskrift for Byhistorisk Forening i Stavanger, Nr. 3/2013, s. 95-107. 
Denham, Sean Dexter, Mari Høgestøl og Grete Lillehammer

2018 A Search Through the Archives: Looking for the Young and the Old in a Museum's Collections. I Across the Generations: The Old and the Young in Past Societies, redigert av Grete Lillehammer

Espedal, Odd og Eileen Murphy: AmS-Skrifter 26, s. 77-90.

1968 Rapport frå førundersøkelse i Stavanger domkirke. Topografisk arkiv, Arkeologisk museum. UiS. Fischer, Gerhard

1964 Domkirken i Stavanger. Kirkebygget i Middelalderen. Dreyers Forlag-Oslo MCMLXIV.

Fyllingen, Hilde og Wenche Brun

2017 Arkeologiske undersøkelser i og rundt Stavanger domkirke. Gnr. 55 og 58, Stavanger k.

Holck, Per Rogaland. Universitetet i Stavanger/Arkeologisk museum Oppdragsrapport 2017/12.

1970 Ein Bericht über die Untersuchung der ausgegrabenen Skelette aus der Kirche auf Moere. Skrifter utgitt av Det Norske Vitenskaps-Akademi i Oslo, I. Mat.-Naturv. Klasse. Ny Serie. No. 28, Oslo 1970, Universitetsforlaget.

Hollund, Hege Ingjerd

2013 Diagenetic screening of bone samples; tools to aid taphonomic and Archaeometric investigations. Ph.D. thesis. UV University Amsterdam: Department for Geo- and Bioarchaeology.

NRF

2019 Researcher Project (FRIPRO). App.no: ES643493; Pr.no: 301877.

Olsen, Haakon

1968 Rapport fra animalosteologisk undersøkelse ved Bergen museum J.S 493. Topografisk arkiv, Arkeologisk museum, UiS.

Reed, Stan

2016 Tusenårsstedet Stavanger. Arkeologiske undersøkelser på Stavanger torg 2004 - 2006. 723 NIKU Oppdragsrapport 73/2016. Del 1: Tekst, del 2: Vedlegg.

Reimer Paula J., Edouard Bard, Alex Bayliss, J. Warren Beck, Paul G. Blackwell, Christopher, Bronk

Ramsey, Caitlin E. Buck, Hai Cheng, R. Lawrence Edwards, Michael Friedrich, Pieter M. Grootes, Thomas

P. Guilderson, Haflidi Haflidason, Irka Hajdas, Christine Hatté, Timothy J. Heaton, Dirk L. Hoffmann, Alan

G. Hogg, Konrad A. Hughen, K. Felix Kaiser, Bernd Kromer, Sturt W. Manning, Mu Niu, Ron W. Reimer,

David A. Richards, E. Marian Scott, John R. Southon, Richard A. Staff, Christian S. M. Turney, Johannes van der Plicht

2013 IntCal13 and Marine13 Radiocarbon Age Calibration Curves 0-50,000 Years cal BP. Radiocarbon 55 (4):1869-1877.

Rolfsen, Perry

1968 Arkeologiske undersøkelser under Stavanger domkirkes kor 1967-68. Rapport. Topografisk arkiv, Arkeologisk museum, UiS.

Sandvik, Paula Utigard

2006 Under overflata i mellomalderbyen Stavanger. Frá haug ok heiđni 3/2006, s. 9-12.

2013 Spora i jorda - Livets memoarer. Stavangeren. Tidsskrift for Byhistorisk Forening i Stavanger, Nr. 3/13, s. 17-32.

2020 Naturvitskapelege undersøkingar frå Tusenårsstedet Stavanger torg. Universitetet i Stavanger/ Arkeologisk museum. Oppdragsrapport 2018/17. Utgjeven i 2020.

Sellevold, Berit Jansen

1991 Fraflyttet antropologisk materiale. Rapport om gjennomgang og registrering av antropologisk materiale funnet på loftet av Domus Media, Univ. i Oslo etter Anatomisk institutts utflytting. Antropologisk Laboratorium, Oldsaksamlingen, Oslo.

van der Sluis, Laura Geerdine

2012 A view into the lives of early Christians: a palaeodietary investigation of a multiperiod churchyard in Stavanger, Norway, using stable isotops $(\mathrm{C}, \mathrm{N} \mathrm{H}, \mathrm{S})$ of bone collagen. I IGBA reports 8 , redigert av Henk Kars, VU University. Amsterdam. 
van der Sluis, Laura Geerdine, Hege Ingjerd Hollund, Henk Kars, Paula Utigard Sandvik og Sean Dexter Denham

2016 A palaeodietary investigation of a multi-period churchyard in Stavanger, Norway, using stable isotope analysis (C, N, H, S) on bone collagen. Journal of Archaeological Science: Reports, Volume 9, s. 120-133.

Torgersen, Johan

1968 Brev til konservator Odmund Møllerop om mottak av skjelett fra Stavanger domkirke, Topografisk arkiv, Arkeologisk museum, UiS.

Torgersen, Johan

Udatert. Brev til mag.art. Perry Rolfsen fra professor Johan Torgersen om skjelett fra Stavanger domkirke, Topografisk arkiv, Arkeologisk museum, UiS.

www.unimus.no Arkeologisøk. 